\title{
A Importância do Primeiro Atendimento no Trauma Ortopédico
}

\author{
MAURICIO KFURI JUNIOR \\ Presidente da Sociedade Brasileira de Trauma Ortopédico
}

Em 1976, um grave acidente vitimou um ortopedista americano, o Dr. Jim Styner, e sua família. O primeiro atendimento dado às vitimas deste acidente mudou a história da atenção ao politraumatizado em todo o Mundo. A constatação de que a falta de um protocolo padronizado de atendimento poderia expor as vitimas de traumatismos à deterioração de seu estado de saúde ou mesmo sequelas importantes motivou a criação do $\operatorname{ATLS}^{\circledR}$ (Advanced Trauma Life Support).

Nos dias de hoje, sabemos que as prioridades no primeiro atendimento ao politraumatizado estão baseadas na preservação da permeabilidade das vias aéreas, na garantia de que o paciente esteja ventilando adequadamente, de que o seu estado hemodinâmico esteja estável.

Qual seria a prioridade do aparelho locomotor no primeiro atendimento a um paciente politraumatizado? A resposta deve ser estruturada sob dois pontos de vista. Se estamos analisando o risco de morte, temos que pensar em lesões associadas a sangramento importante, como as fraturas do anel pélvico, e as fraturas múltiplas de membros. Do ponto de vista da função do membro, as emergências passam a ter um espectro maior. Neste sentido estão a contaminação, evidente em fraturas expostas, e as lesões que comprometem a perfusão do membro, como as síndromes compartimentais e as lesões de impacto sistêmico, como os traumatismos raquimedulares.

São muitos os embates nas salas de urgência pelo Brasil, quando estamos diante de uma emergência ortopédica. Quantas não são as vezes em que se discute se o que deve ser feito primeiro é a laparotomia exploradora ou a fixação imediata do anel pélvico? A resposta para estas polêmicas deve estar fundamentada em argumentos técnicos. Não há duvida de que a estabilização pélvica é essencial para o controle do choque hipovolêmico. Mas esta fixação deve ser rápida e realizada de tal forma que não interfira com possíveis abordagens abdominais subseqüentes ou concomitantes.

E o que dizer das urgências ortopédicas do pronto socorro no dia-a-dia? Quantos de nós seguimos protocolos para lidar com situações cotidianas tais como amputações de ponta de dedo, fratura supra-condileana do úmero na criança, fratura trocanteriana no idoso ou fratura exposta da perna?

Pensando na necessidade de oferecer diretrizes para o primeiro atendimento ao trauma ortopédico cotidiano, desenhamos um programa de educação itinerante, que deve percorrer o território nacional com cursos presenciais.

Trata-se do SBTO: Suporte Básico no Trauma Ortopédico. O SBTO deverá ocorrer no período de junho de 2011 a maio de 2012. Trata-se de um curso itinerante, a ser ministrado aos sábados, no período das 8 às 13:30hs. O objetivo do SBTO não é apresentar o estado da arte na fixação de fraturas, mas o que deve ser feito no primeiro atendimento das urgências mais frequentes na área do trauma ortopédico. Cada curso deve ser destinado a um grupo de 15 a 20 médicos e contará com um professor. A idéia é estimular a interatividade. No total estão previstos 40 cursos, percorrendo a maioria dos Estados brasileiros. $\mathrm{O}$ suporte logístico aos cursos será oferecido pela iniciativa privada. Duas empresas apóiam a Sociedade Brasileira do Trauma Ortopédico nesta iniciativa: Sanofi-Aventis e Cortical Produtos Cirúrgicos.

Projetos de educação continuada bem sucedidos são uma marca da Sociedade Brasileira de Ortopedia. Com o estabelecimento desta plataforma de ensino complementar, a Sociedade Brasileira de Trauma Ortopédico busca atender uma reivindicação dos ortopedistas brasileiros, manifestada em pesquisa Datafolha, publicada neste suplemento, onde tais atividades são consideradas prioritárias para a melhoria do exercício profissional.

A Sociedade Brasileira de Trauma Ortopédico deseja valorizar o ortopedista dedicado ao trauma. Mais do que isso: ela quer ser uma prestadora de serviços para a comunidade ortopédica, defendendo os seus interesses e os seus anseios. 